\title{
What prevents knowledge inequalities among citizens from increasing? Evidence from direct-democratic campaigns in Switzerland
}

\author{
Laurent Bernhard, University of Lausanne, Swiss Centre of Expertise in the Social Sciences (FORS)
} laurent.bernhard@fors.unil.ch

\begin{abstract}
This article seeks to enrich the normative debate on the advantages and drawbacks of direct democracy through an empirical analysis of individual learning about the contents of ballot propositions during campaigns. Following the knowledge gap paradigm, this article examines the factors that prevent socio-economic-knowledge inequalities among citizens from increasing. I argue that ballot propositions of low complexity exert a moderating influence, since such environments provide citizens with easy learning situations. The empirical analysis, based on panel survey data on three federal level votes that took place in Switzerland from 2006 to 2008, supports the issue complexity hypothesis.
\end{abstract}

Keywords

Switzerland, direct democracy, campaigns, political knowledge

\section{Introduction}

Direct democracy remains very controversial. When assessing the benefits and shortcomings of referendums and initiatives, considerations about the competence of citizens prove to be of crucial importance. Critics of direct legislation usually emphasize that citizens are not sufficiently qualified to directly participate in political decisions (see Budge, 1996, p. $59 \mathrm{ff}$.). From an elitist point of view, participatory democracy in general, and direct democracy in particular, is considered to be too demanding for ordinary citizens (Schumpeter, 1942). This scepticism is shared by many influential political theorists who fear that direct democracy could lead to a reinvigoration of extremism. Dahl (1956) famously argues that extending participation rights to ordinary people can be dangerous, as such reforms may lead to increasing political activity among lower socio-economic classes, thus provoking a rise of authoritarian ideas. In a similar vein, Sartori (1987, p. 120) expects that direct democracy "would quickly and disastrously founder on the reefs of cognitive incompetence." In line with such con- cerns, early public opinion research carried out in the United States in the 1950s and 1960s largely confirms the ignorance and incompetence of large parts of the citizenry. The paradigm of "minimalism" maintains that mass publics are characterized by low levels of political attention and competence (Sniderman, 1993, p. 219).

From a participatory point of view, however, it is believed that direct democracy empowers citizens by increasing their political capabilities. In concert with the major arguments proposed by theorists of participatory democracy (Barber, 1984; Pateman, 1970), proponents of direct democracy tend to adhere to the view that the opportunity to participate in direct-democratic votes leads citizens to acquire the necessary skills and capabilities. As a consequence, this theory suggests that granting people more voice is a promising remedy against the current crisis of democracy (Cain, Dalton, \& Scarrow, 2003).

In recent years, scholars have built an impressive body of literature about the secondary effects of direct democracy. Overall, the empirical work suggests that direct democracy bolsters civic orientations (Frey, 1997). As to political knowl- 
edge, empirical studies indeed show that voters are generally more politically aware of political issues when they have a say in policy decision-making (Benz \& Stutzer, 2004; Smith \& Tolbert, 2004; Smith \& Tolbert, 2007; Smith, 2002).

Yet, despite these rather encouraging findings about the educative effects of direct democracy, a major concern must be addressed from a normative point of view. While the occurrence of referendums and initiatives seems to increase factual knowledge in political matters, these studies also find considerable inequalities in terms of the socio-economic status (SES) of voters. Specifically, citizens with higher levels of formal education have been shown to be more competent. In other words, political knowledge appears to follow a highly discriminatory logic. The positive educative spillover effects caused by exposure to direct democracy thus tend to be confined to people with above-average SES.

This article seeks to enrich the normative debate on the advantages and drawbacks of direct democracy through an empirical analysis of individual learning about the contents of ballot propositions during campaigns. Following the knowledge gap paradigm (Tichenor, Donohue, \& Olien, 1970), I examine the conditions that moderate resource-based inequalities. Past research reveals that the effects of political communication depend on two sets of characteristics - the predispositions of individuals and the more general context of the political communication (Iyengar \& Simon, 2000). In this empirical contribution, I focus on the interplay between these two levels. My hypothesis is that the discriminatory effects of socio-economic status on learning disappear when propositions of low issue complexity are at stake. The empirical part of this study employs panel survey data collected in the framework of three direct-democratic campaigns held in Switzerland from 2006 and 2008. The results support the issue complexity hypothesis.

This article is structured as follows. In Section 2, I develop my theoretical argument, which culminates in the formulation of my issue complexity hypothesis.
Section 3 describes the three ballot propositions selected for this study. In Section 4 , I provide an overview of the panel data and the indicators I employ. Section 5 presents the results through descriptive and multivariate analyses. Section 6 provides a concise overview of this article.

\section{The moderating role of issue complexity}

Ballot propositions are simple binary choices where voters are able to vote "yes" or "no." However, these propositions relate to political decisions that usually have important and far-reaching policy consequences. Since citizens have the final say, it appears crucial that they are aware of the contents of the propositions that are submitted to the ballot. In order to arrive at a reasoned choice, direct democracy imposes high demands on citizens in terms of their level of issue-specific knowledge.

Some scholars suggest that voters can rely on shortcuts and simple cues, such as recommendations issued by the government or their preferred party when making their choice (Kriesi, 2005; Lupia \& Matsusaka, 2004). This heuristic strategy reduces the effort necessary to make a reasoned choice. In a widely cited study on insurance propositions conducted in California, Lupia (1994) shows that voters who rely on shortcuts tend to vote the same way as those who possess deep encyclopedic knowledge. However, the use of this minimalist strategy can pose some risk to poorly informed citizens. Indeed, the literature on correct voting (Lau \& Redlawswk, 2008) suggests that people cannot systematically be expected to vote as if they had full knowledge about the propositions at stake. In the case of Swiss direct-democratic votes, several empirical analyses reveal that citizens who lack issue-specific knowledge are less likely to vote in accordance with their own preferences than those who are well informed (Lanz \& Nai, 2015; Milic, 2012; Nai, 2015). It is thus advantageous for individuals if they base their choices on substantive considerations. In order to cast a reasoned ballot, a 
minimal level of issue-specific knowledge seems to be necessary.

Yet in light of their low levels of political knowledge (Delli Carpini \& Keeter 1996), ordinary citizens cannot generally be expected to have such information when referendums and initiatives are placed on the ballot. Political communication scholars believe that the campaigns that precede the votes are crucial for citizens' acquisition of factual knowledge. Campaigns create an environment that is conducive to political learning by greatly increasing the flow of information to citizens (Zaller, 1992; Nadeau, Nevitte, Gidengil, \& Blais, 2008). In the case of direct democracy, competing political elites and the media face great incentives to provide citizens with a huge amount of information about the contents of the ballot propositions at stake (Kriesi, 2011). When exposed to such intensive campaigns, citizens are thus expected to gain substantial relevant issue-specific knowledge.

However, as has long been observed, citizens are differently endowed with resources that they can use in politics (Verba et al., 1978). This means that gains in knowledge may not be equally distributed among citizens. The influential knowledge gap hypothesis (Tichenor et al., 1970) posits that the process of knowledge acquisition of highly publicized topics diverges across socio-economic strata. Based on the assumption that there is a gap in knowledge between high and low SES groups at the beginning, the classic hypothesis expects a widening of this gap as a result of the flow of information provided by political actors and journalists. Several rationales have been proposed for the expectation that individuals with a high SES tend to acquire information at a faster pace than individuals with a lower SES. Amongst others, the former tend to possess better communication skills, higher levels of existing knowledge, more social contacts as well as greater attention to the mass media (Hwang \& Jeong, 2009).

In the last decades, numerous panel studies across a wide range of issues and countries have supported the knowledge gap hypothesis (Bonfadelli, 1994;
Hwang \& Jeong, 2009). This empirical work reveals significant positive associations between education, on the one hand, and knowledge levels on political matters, on the other. However, patterns showing stable, and even decreasing inequalities, have also emerged from a non-negligible amount of empirical analyses. Similarly, Holbrook's (2002) comprehensive study of six US presidential elections reveals that knowledge gaps do not always widen over the course of campaigns. The state of the art thus prompts the question: under what conditions is a broadening of knowledge inequalities most likely not to occur.

Hereafter, I will argue that the relationship between socio-economic status and issue-specific learning is moderated by the level of issue complexity. When faced with complex issues, it is hypothesized that during political campaigns individuals with a high SES learn more about the issue at stake than individuals with a low SES. This expectation is based on the rationale that the appropriation of relevant information is demanding in circumstances of high issue complexity. Thus, the process of knowledge acquisition may follow a discriminatory logic that works to the advantage of individuals with a high SES, thus leading to a widening of (presumably) existing knowledge gaps. In line with this consideration, Bonfadelli (2005, p. 44) observes that the knowledge gap hypothesis tends to perform particularly well when scholars investigate scientific, technological and health-related issues. Indeed, all of these topics can be considered to be of a rather complex nature. In contrast, the knowledge gap is expected to remain stable, or even diminish, when propositions of low complexity are submitted to the vote. The rationale behind this hypothesis is that individuals with a low SES will not have any major difficulties understanding the content of the proposition. In other words, citizens find themselves in what Zaller (1992) calls an "easy learning situation." In such as a situation, learning should not be systematically dependent on the socio-economic status of individuals. 
In what follows, I propose to conceive of issue complexity as a three-dimensional phenomenon in the context of direct democracy. Accordingly, complex ballot propositions are characterized by 1 ) a wide range of issues, 2) a large number of issues and 3) a high degree of technical complexity. Following Gormley (1986, p. 598), the latter means that specialized knowledge and training are needed if a given issue is to be satisfactorily addressed.

In the Swiss variant of direct democracy at the federal level (see Kriesi \& Trechsel, 2008), popular initiatives generally qualify as ballot propositions of low complexity. These votes usually contain one single topic, a very restricted number of issues and are characterized by a low level of technical complexity. Popular initiatives are propositions "from below" and are formulated by organizations that have been unable to channel their demands through legislation.

In terms of scope, the texts of initiatives must be thematically focused on a single topic. In addition, the number of issues and the level of technical complexity tend to be low. These two features can be attributed to the fact that popular initiatives always refer to modifications to the constitution. This is the domain of guiding principles. As a consequence, the texts of popular initiatives are usually no longer than a page, given that they mostly only contain one or a few demands. As opposed to legislative bills, these demands are generally easy to understand. In other words, no specialized knowledge is required to understand the meaning of the content.

In contrast, referendums follow a reverse logic, since these votes deal with propositions "from above." Referendums concern legislative bills that have been previously approved by Parliament. Such votes, therefore, constitute a final hurdle to be taken. Unlike initiatives, referendums offer the opportunity to block a reform project (i.e. to defend the status quo). Referendums take two basic forms. While compulsory referendums refer to the constitution, optional referendums are subject to regular legislation. For pragmatic reasons, I only assess the level of issue complexity in the optional referendum, since the cases in the empirical analysis do not include any mandatory referendums. ${ }^{1}$

With respect to the range of issues, the bills subject to optional referendums prove to be rather narrow in scope. The pieces of legislation that can be submitted to the vote usually focus on a particular topic. However, legislative bills sometimes contain sub-issues that are closely related to other issue domains. Nevertheless, optional referendums have rather low levels of complexity in terms of the range of issues. However, this is not the case regarding the number of issues. Given that optional referendums concern legislative bills adopted by Parliament, these votes are typically characterized by a multitude of articles and a large number of new policy measures. Finally, the contents of optional referendums are characterized by a high level of technical complexity. Again, this is can be attributed to the fact that articles are set up at the level of regular legislation, which contains detailed provisions.

To summarize, optional referendums tend to be much more complex than popular initiatives, especially in regard to the number of issues and their technical complexity. Thus, I classify the former as having high issue complexity and the latter as having of low issue complexity. My hypothesis predicts that SES-based knowledge inequalities widen in the case of optional referendums and remain constant in the case of popular initiatives.

\section{Case selection}

This study analyzes three direct-democratic campaigns that took place in Switzerland between 2006 and 2008. Such campaigns typically involve a considerable intensification of political communication

1 In terms of issue complexity, mandatory referendums are similar to popular initiatives. The fact that most votes of this type involve the constitutional level denotes a low number of issues and a low level of technical complexity. In addition, propositions use to be narrow in scope and thus address a very restricted range of issues. 
and have a limited duration of around two months (Kriesi 2011). As represented in Table 1, the selected cases vary in their direct-democratic institutions and their policy domains. Two campaigns precede optional referendums, while the remaining one precedes a popular initiative. One referendum campaign and the initiative pertain to the domain of immigration policy. These propositions represent two cases that are typical of this policy domain - a referendum launched by the left against the tightening of the asylum law and an initiative launched by the right in favour of a more restrictive naturalization policy. The third campaign deals with fiscal matters, specifically a neoliberal corporate tax reform against which the left forced a referendum.

Table 1: Overview of the selected ballot propositions

\begin{tabular}{l|ll}
\hline $\begin{array}{l}\text { Direct-democratic } \\
\text { institution }\end{array}$ & $\begin{array}{l}\text { Policy domain } \\
\text { Immigration policy }\end{array}$ & Fiscal policy \\
\hline Optional referendum & Asylum law & $\begin{array}{l}\text { Corporation tax } \\
\text { reform }\end{array}$ \\
Popular initiative & $\begin{array}{l}\text { Naturalization } \\
\text { initiative }\end{array}$ & \\
\hline
\end{tabular}

The remaining part of this section provides an overview of the three cases. ${ }^{2}$ The first campaign is related to a referendum against a revision of the asylum law, which was backed by moderate and radical right parties. This reform was a clear case of tightening, as it contained a series of restrictive measures towards asylum seekers. Immediately following the adoption by Parliament, parties from the left and civil society groups launched a referendum challenge. These organizations did not have difficulty qualifying the legislative bill for the ballot. The vote was preceded by a long, spirited and intense campaign. On 24 September 2006, Swiss voters accepted the reform of the federal asylum law by a large majority of 67.7 per cent.

2 Kriesi (2011) and Bernhard (2012) provide additional information about these campaigns.
I now address the second case. In 2005, the radical right Swiss People's Party (SVP) submitted an initiative on naturalizations, in reaction to a ruling by the Federal Court. ${ }^{3}$ The initiative proposed that voters in a given municipality be able to decide on the kind of procedure to adopt for naturalizations - specifically on whether they wanted to vote on individual naturalizations at the ballot box. Moreover, the initiative stipulated that it not be possible to appeal the rejections of naturalization requests. The campaign took place in spring 2008 and turned out to be very heated, as it gave rise to opposition between two key figures of Swiss politics at that time-Christoph Blocher, the charismatic leader of the Swiss People's Party, who was surprisingly voted out of the government by a majority of Parliament some months before, and Eveline Widmer-Schlumpf, his successor as Minister of Justice, whose cantonal branch was excluded from the SVP because she accepted her replacement of Blocher against the will of the party. A TV debate on this proposition was followed by a record audience several weeks before the vote. On 1 June 2008, 63.6 per cent of participating voters rejected the naturalization initiative.

The third selected case, the corporate tax reform, was designed to strengthen small and middle-sized firms (SMEs), which are often considered to be the backbone of the Swiss economy. The reform proved to be of an extraordinarily high level of technical complexity, including a tax cut on dividends for large shareholders and various special measures for SMEs. After the moderate and radical right passed the bill in Parliament, against the votes of the left, the latter forced a referendum. During the weeks that preceded the vote, the Swiss business community led an intensive and well-orchestrated campaign in support of the bill. It came as quite a surprise that, on 24 February 2008, the corpo-

3 In order to avoid arbitrary decisions, the judges stated that rejected citizenship applications had to be justified. This decision de facto banned secret ballot votes. This procedure had been subject to heated criticism and media attention. 
rate tax reform was accepted by a narrow majority of only 50.5 per cent.

\section{Data and operationalization}

This analysis is based on an integrated dataset that combines content analysis with panel survey data using media use variables (see Bernhard 2018 for a similar analysis). Information about the survey respondents' preferred newspapers and political television (TV) shows allows for news reporting information to be included into the panel dataset. The latter is based on individual-level data collected in the framework of a two-wave survey conducted for each of the three campaigns in the German and the French language regions of Switzerland. ${ }^{4}$ The first waves were conducted at the beginning of the campaigns (i.e. approximately two months before Ballot Day), the last waves were conducted immediately following the official voting date. I include respondents who answered both waves, resulting in 1092 (asylum law), 999 (naturalization initiative) and 1001 (corporate tax reform) respondents. Three independent samples were recruited by random quota. In order to minimize drop-out, the interviewees received an incentive for their participation. The samples are representative in terms of the respondents' sex, age and place of residence. However, there is a bias in terms of education. Due to panel mortality biases, the lowest educational levels are underrepresented in the sample. ${ }^{5}$ Computer assisted telephone interviews (CATI) lasted about 20 to 30 minutes for each wave. For the content analysis, the most important quality newspapers, free newspapers, news magazines, regional newspapers, tabloid newspapers, public service TV news and TV shows in the German and

4 In the case of the asylum law referendum, a three wave survey was conducted (Kriesi, 2011). However, for the sake of comparability across campaigns, I omitted the second one.

5 The underrepresentation of the lowest education levels does not affect the findings of this study.
French-speaking parts of the country were selected. ${ }^{6}$

The study's indicators were constructed as follows. To measure the dependent variable (i.e. individual level of learning from the beginning to the end of the selected campaigns), I rely on factual knowledge questions about the propositions in question. As opposed to general questions about general political knowledge, this approach is designed to capture "practical knowledge" (Lupia, 2006). Indeed, to reach a competent decision in direct-democratic votes, citizens must be informed of the contents of the propositions at stake. For each ballot proposition, respondents were asked three issue-specific questions. ${ }^{7}$ The nine items used in this analysis, as well as the correct answers, are listed in Table 2. Respondents had three response options "yes," "no" and "do not know." For each respondent, I first count the number of correct answers in both panel waves. "Do not know" answers were given a zero, while incorrect answers were deducted one point. The rationale behind this penalization is that uninformed respondents who adopted guessing strategies had a 50 per cent probability of guessing the correct answer (Mondak, 2001). Overall, negative scores were set at zero for each wave. Hence, issue-specific knowledge levels range from 0 to 3 . Subsequently, I calculate the extent of individual learning by subtracting the respondents' knowledge scores in the first wave from the second wave. Hence, the learning indicator theoretically ranges from -3 to 3 .

Let me now turn to the independent variable. As is standard practice in the knowledge gap literature, socio-economic status is measured by individuals' levels of formal education. I apply the classification used by the Swiss Federal Office of Statistics regarding educational achievements.

6 The selected media outlets are listed in Kriesi (2011).

7 Given that the popular initiative on naturalizations only consisted of two demands, two items refer to the same issue. As demonstrated in Table 2, the first and the third question concern the organizational body in charge of naturalization decisions at the local level. 
Table 2: Issue-specific knowledge questions according to ballot proposition

\begin{tabular}{|c|c|c|}
\hline Campaign & Question & $\begin{array}{l}\text { Correct } \\
\text { answer }\end{array}$ \\
\hline Asylum & $\begin{array}{l}\text { 1) Does the law stipulate that asylum-seekers have to possess identity papers in order to apply for asylum? } \\
\text { 2) Does the law allow excluding rejected asylum-seekers from social assistance? } \\
\text { 3) Does the law in principle allow accepting demands of asylum-seekers who can return to a safe third country? }\end{array}$ & $\begin{array}{l}\text { No } \\
\text { Yes } \\
\text { No }\end{array}$ \\
\hline Naturalization & $\begin{array}{l}\text { 1) Does the initiative demand that only the people will decide on naturalization requests in the future? } \\
\text { 2) Does the initiative interdict that decisions on naturalizations can be contested before Court? } \\
\text { 3) Does the initiative leave it to the communes to choose the body in charge of naturalization decisions? }\end{array}$ & $\begin{array}{l}\text { No } \\
\text { Yes } \\
\text { Yes }\end{array}$ \\
\hline Corporate tax & $\begin{array}{l}\text { 1) Does the reform provide tax reliefs for all kind of dividends? } \\
\text { 2) Does the reform allow for alleviating the firms' tax on capital at the cantonal level? } \\
\text { 3) Does the reform introduce fiscal measures for personal companies in a period of transition? }\end{array}$ & $\begin{array}{l}\text { No } \\
\text { Yes } \\
\text { Yes }\end{array}$ \\
\hline
\end{tabular}

This scale ranges from zero ("no graduation") to 12 ("university degree").

In addition, I include a series of control variables. Evidently, political interest is a "usual suspect" in the field of knowledge inequalities studies. For this variable, I employ a scale ranging from $1=$ "not interested at all" to $4=$ "very interested." Given that the issue of the gender gap has proven to be rather salient in the scholarly literature (Fraile 2013; Ferrin Pereira, Fraile, \& Rubal, 2015), I also account for sex (woman $=1$, men $=0$ ). In addition, the effect of age is modelled by using the respondents' age and a quadratic term in order to observe curvilinear patterns. Based on the tripolar party configuration that exists in Western Europe (Kriesi et al. 2008), I also consider individuals' political camp by distinguishing between voters from the left (Social Democrats and the Green Party of Switzerland), the moderate right (Christian Democrats and Liberals) and the radical right (Swiss People's Party). An individual's preferred party is identified based on questions relating to voting probabilities. ${ }^{8}$ The responses range from "will never vote for this party" (score 0 ) to "will certainly vote

8 A stricter definition of party identification or party choice in the last election or in a hypothetical election next Sunday results in a large amount of non-responses in Switzerland. Partisan preferences is designated on the basis of a set of questions that ask respondents to indicate how likely they are to ever vote for the five most important parties: the Greens, the Social Democrats, the Christian-Democrats, the Liberals and the Swiss People's Party. for this party at some time in the future" (score 10). I assign respondents to a given camp based on the highest party score.

Finally, I include mass media exposure and attentiveness. In both cases, I distinguish between TV and newspapers, since the latter usually provides citizens with more elaborate information (Fraile, 2010). However, there is an obvious lack of consensus as far as the appropriate measurement of media exposure is concerned. Capturing an individual's informational environment proves to be very difficult. Indeed, Goldstein and Freedman (2002) call it a vexing challenge. In line with the fundamental assumption that "people are influenced by mass communication in proportion to the amount of it they receive" (Zaller, 1996, p. 33), my indicator for media exposure corresponds to the respective number of arguments the respondents received during the campaign in their preferred TV show and newspaper. As far as media attentiveness is concerned, I rely on two questions that asked respondents about the extent to which they usually pay attention to TV and newspapers (from 1 "no attention at all" to 5 "a great deal of attention"). Finally, I consider the role played by interpersonal communication. To that end, I use the answer to an item that refers to the vote under scrutiny. Participants were asked how many times they had private discussions with relatives, friends or colleagues about the topic of the ballot proposition in the last few weeks. Again, the scale ranges from 1 "very rarely" to 5 "very often." 


\section{Empirical analysis}

The analysis is carried out in two steps. First, I resort to descriptive analyses in which I outline the knowledge levels and the magnitude of learning for each of the three selected campaigns. Second, I turn to the multivariate analysis by testing the issue complexity hypothesis.

\subsection{Descriptive analysis}

Table 3 provides an overview of individuals' knowledge levels at the outset of the three campaigns and at their ends. The highest level of initial knowledge is observed for the asylum law (0.70). In contrast, this figure proves to be much lower for the two remaining cases $(0.28$ for the naturalization initiative and 0.23 for the corporate tax reform). This sharp difference can be attributed to the fact that an unusually high number of media reports were published about the asylum law before the campaign entered into its hot phase in the last few weeks. Thus, many voters were familiar with the proposition's content when the first wave of the panel survey took place. At the end of this campaign, respondents remained most knowledgeable about the asylum law (1.52), followed by the naturalization initiative (1.05), and the corporate tax reform (0.87). The intermediate position of the campaign on naturalization is somewhat surprising. Given that this proposal was characterized by a low level of issue complexity, citizen competence should have been highest in this case. A closer look reveals that respondents had a difficult time correctly answering the first knowledge question (see Table 2). Indeed, it is striking to observe how knowledge levels with respect to this item even slightly decreased. ${ }^{9}$

More generally, it appears that learning occurred during these campaigns. In terms of magnitude, there are no large differences across the three cases under scrutiny $(+0.82$ for the asylum law, +0.76 for the naturalization initiative and +0.64 for the corporate tax reform). It can thus be asserted that respondents learnt a great

9 Among the nine knowledge items studied, this negative difference is an exception. deal about the issue-specific provisions of the ballot propositions. It is important to note that the amount of issue-specific learning is highest in the case of the naturalization initiative when the item that caused a lot of confusion among respondents is removed. Many citizens believed that the initiative demanded that citizens should decide on naturalization requests (by means of ballot votes at the local level). In fact, the initiative was much less constraining: the text stipulated that municipalities should be free to decide on the kind of procedures that they would like to apply. Finally, the comparatively low levels of both initial knowledge levels and learning in the corporate tax reform case are consistent in light of its extraordinarily high level of complexity.

Table 3: Issue-specific knowledge levels and learning, by campaign

\begin{tabular}{l|ccc}
\hline $\begin{array}{l}\text { Knowledge level } \\
\text { and level of } \\
\text { learning }\end{array}$ & Asylum & Naturalization & Corporate tax \\
\hline Knowledge (t1) & 0.70 & 0.28 & 0.23 \\
Knowledge (t2) & 1.52 & 1.05 & 0.87 \\
Learning & +0.82 & +0.76 & +0.64 \\
\hline
\end{tabular}

\subsection{Multivariate analysis}

Before addressing my hypothesis, I will briefly present the determinants of initial knowledge levels. The ordered probit regression models (in the Appendix to this article) contain the independent variables outlined in the previous section, with the exception of campaign-specific factors (i.e. the two indicators on exposure and the item about interpersonal discussions). As demonstrated in Table A.1, the level of formal education is only significant for the case of the asylum law. Remarkably, education-based inequalities are unable to explain individual levels of issue-specific knowledge at the outset of the campaigns for the naturalization initiative and the corporate tax reform. These findings call into question the basic assumption of the knowledge gap paradigm. In contrast, initial knowledge is found to depend positively on levels of political interest. This 
relationship proves to be significant in all three campaigns. In addition, the analysis reveals that voters from the left were most knowledgeable about the ballot measure on asylum policies. This result can be attributed to the strong public involvement of the left and their allies during the pre-campaign period, since these actors did not interrupt their mobilization efforts after having collected the required number of signatures (Bernhard 2012).

In the case of issue-specific learning, I make two important decisions in order to deal with the challenge posed by ceiling effects. First, I omit individuals from the analysis who provided correct answers to all three questions in the first wave survey, since these respondents are unable to acquire additional knowledge. ${ }^{10}$ Second, I decide to account for initial knowledge levels. The rationale behind this choice is that it is expected that learning potentials should be largest for respondents who are not knowledgeable at the beginning of the campaigns. In other words, individuals who are already knowledgeable about the issues at stake before the beginning of the campaign cannot learn much afterwards.

Consistent with this line of reasoning, Table 4 shows that there is a strong negative association between initial knowledge levels and the magnitude of issue-specific learning during all three campaigns. With respect to formal education, the findings are in line with my hypothesis. According to the estimation models, there are significant education-based disparities in terms of issue-specific learning regarding the two optional referendums, i. e. the asylum law and the corporate tax reform. In contrast, the coefficient for the popular initiative on naturalizations is not statistically significant. These results support the view that learning follows a resource-based logic when ballot propositions of high complexity are at stake. On the contrary, in the case of popular initiatives, citizens find themselves in easy learning situations. As a consequence, when confronted with

10 This affected 139 respondents in the case of the asylum law, 39 respondents in the case of the naturalization initiative and 34 respondents in the case of the corporate tax reform. these kinds of ballot propositions, individuals with low levels of formal education do not tend to learn more from the campaigns than those with lower levels.

With respect to the control variables, the level of an individual's political interest only appears to be instrumental to learning in the case of the corporate tax reform. This positive relation may be due to the high technical complexity of this proposition. In such a difficult learning situation, individuals with high political interest may be much more motivated than the remaining individuals to acquire issue-specific knowledge. Regarding the vote on naturalization, there are two significant associations. First, women turn out to have learnt less than men, a finding that has no satisfactory explanation. Unquestionably, the domain of political rights (including questions pertaining to naturalizations) has historically been a men's affair in Switzerland. However, the absence of a gender gap at the outset of the campaign seems to somewhat cancel out this line of reasoning. Second, it is interesting to note that exposure to TV leads to greater issue-specific knowledge during this campaign. As mentioned in the section on case selection, it is precisely in the case of the naturalization initiative that TV shows play an important role. Regarding the asylum law, voters from the radical right have learnt significantly less than the voters from the left and the moderate right. It may be possible that most adherents of the Swiss People's Party did not consider it necessary to grapple with the proposition's content because simply knowing that the revised asylum law contained tightening measures may have reassured them that they were consistently voting with their predispositions.

Regarding the control variables, I have to admit that I accounted for the determinants which are generally used in the knowledge literature. A reviewer convincingly observed that those variables which can be expected to causally follow the independent variable (i.e. education) should be dropped in order to avoid post-treatment biases. Based on these considerations, I decided to rely on alter- 
Table 4: $\quad$ Ordered probit regression models explaining levels of issue-specific learning

\begin{tabular}{|c|c|c|c|}
\hline Variables & $\begin{array}{l}\text { Asylum } \\
\text { (1) }\end{array}$ & $\begin{array}{l}\text { Naturalization } \\
\text { (2) }\end{array}$ & $\begin{array}{c}\text { Corporate tax } \\
\text { (3) }\end{array}$ \\
\hline Initial knowledge & $\begin{array}{l}-0.595^{* * *} \\
(-10.80)\end{array}$ & $\begin{array}{l}-0.634^{* * *} \\
(-7.72)\end{array}$ & $\begin{array}{l}-0.685^{* * *} \\
(-9.51)\end{array}$ \\
\hline Education level & $\begin{array}{l}0.049^{* * *} \\
(3.67)\end{array}$ & $\begin{array}{l}0.019 \\
(1.38)\end{array}$ & $\begin{array}{l}0.033^{* *} \\
(2.70)\end{array}$ \\
\hline Political interest & $\begin{array}{l}0.065 \\
(1.08)\end{array}$ & $\begin{array}{r}0.096 \\
(1.68)\end{array}$ & $\begin{array}{l}0.208^{* * * *} \\
(3.77)\end{array}$ \\
\hline Woman & $\begin{array}{l}0.043 \\
(0.55)\end{array}$ & $\begin{array}{l}-0.194^{*} \\
(-2.41)\end{array}$ & $\begin{array}{l}-0.066 \\
(-0.85)\end{array}$ \\
\hline Age & $\begin{array}{l}-0.025 \\
(-1.92)\end{array}$ & $\begin{array}{l}-0.005 \\
(-0.37)\end{array}$ & $\begin{array}{l}0.012 \\
(0.89)\end{array}$ \\
\hline $\mathrm{Age}^{2}$ & $\begin{array}{l}0.0001 \\
(1.17)\end{array}$ & $\begin{array}{l}0.0000 \\
(0.23)\end{array}$ & $\begin{array}{l}-0.0001 \\
(-0.41)\end{array}$ \\
\hline Left & $\begin{array}{l}0.346^{* * *} \\
(3.72)\end{array}$ & $\begin{array}{r}0.054 \\
(0.60)\end{array}$ & $\begin{array}{l}-0.154 \\
(-1.71)\end{array}$ \\
\hline Moderate right & $\begin{array}{l}0.225^{*} \\
(2.41)\end{array}$ & $\begin{array}{l}0.019 \\
(0.19)\end{array}$ & $\begin{array}{l}-0.009 \\
(-0.09)\end{array}$ \\
\hline TV exposure & $\begin{array}{r}-0.000 \\
(-0.01)\end{array}$ & $\begin{array}{l}0.002^{*} \\
(2.43)\end{array}$ & $\begin{array}{r}0.001 \\
(1.09)\end{array}$ \\
\hline Newspaper exposure & $\begin{array}{r}-0.000 \\
(-0.27)\end{array}$ & $\begin{array}{r}-0.000 \\
(-0.88)\end{array}$ & $\begin{array}{r}0.000 \\
(0.81)\end{array}$ \\
\hline TV attention & $\begin{array}{l}-0.239 \\
(-1.81)\end{array}$ & $\begin{array}{c}0.179 \\
(1.26)\end{array}$ & $\begin{array}{r}0.064 \\
(0.45)\end{array}$ \\
\hline Newspaper attention & $\begin{array}{l}0.042 \\
(0.33)\end{array}$ & $\begin{array}{l}-0.093 \\
(-0.73)\end{array}$ & $\begin{array}{r}-0.101 \\
(-0.78)\end{array}$ \\
\hline Interpersonal discussions & $\begin{array}{r}0.127 \\
(0.88)\end{array}$ & $\begin{array}{r}0.024 \\
(0.16)\end{array}$ & $\begin{array}{r}0.121 \\
(0.82)\end{array}$ \\
\hline $\mathrm{N}$ & 897 & 951 & 954 \\
\hline Pseudo $\mathrm{R}^{2}$ & 0.076 & 0.046 & 0.055 \\
\hline
\end{tabular}

Note. Z-Values in parentheses.

${ }^{*} p \leq 0.05,{ }^{* *} p \leq 0.01,{ }^{* * *} p \leq 0.001$.

Supporters of the radical right serve as reference category for the political camp.

native specifications by removing political interest, camp affiliations, media exposure, media attention, and interpersonal discussions from the models presented in Table 4. In so doing, I obtained the same results in terms of statistical significance for the remaining variables.

Due to another sensible remark made by a reviewer, I also tested the issue complexity hypothesis in a single model. To that end, I merged the three campaign data sets. As explanatory factors, I introduced - in addition to the variables listed in Table 4-a dummy variable for optional referendums (i.e. " 1 " for the asylum law and corporate tax reform and " 0 " for the initiative on naturalizations) as well as an interaction term between formal education levels and optional referendums. The latter turns out to be positively significant at the 5 per cent error level. Hence, formal education appears to be instrumental for issues-specific learning when individuals face optional referendums. This finding is in line with my hypothesis.

\section{Conclusion}

The question of the relative merits of direct democracy over representative democracy has long given rise to an insurmountable divide between proponents and opponents of extended popular rights. While the former emphasize that the use of referendums and initiatives empower citizens, the latter argue that ordinary voters lack the ability to make reasoned choices on ballot propositions. In the last decades, 
this controversy has been nurtured by a vast amount of empirical studies.

In this article, I focus on factual knowledge gains during direct-democratic campaigns. More specifically, the present contribution examines the moderating role played by issue complexity in regard to the relationship between education-based inequalities and learning about the content of ballot propositions. Based on survey panel data available for three Swiss direct-democratic campaigns on the topics of asylum, naturalizations and corporate taxes, the results suggest that issue-specific learning is positively related to an individual's level of formal education when complex ballot propositions are at stake (i.e. optional referendums). Conversely, learning does not prove to be discriminatory when proposals of low issue complexity (i.e. popular initiatives) are submitted to the vote.

Arguably, the most interesting byproduct of this empirical analysis concerns the finding that levels of knowledge at the outset of campaigns are not always a function of formal education. Only in the case of the asylum law do the results reveal education-based inequalities in citizens' initial levels of knowledge. Moreover, this knowledge gap tends to be reinforced during this particular campaign. The naturalization initiative constitutes a contrasting case. The absence of both knowledge gaps and unequal learning patterns sheds a positive light on this campaign. The corporate tax reform is an ambivalent case. While there was no knowledge gap at the beginning of the campaign, formal education plays a major role in the acquisition of issue-specific knowledge.

I would like to emphasize that I am somewhat reluctant to generalize the findings obtained in the framework of this study. First, and most obviously, this research has only dealt with three campaign contexts. This limited number causes some apprehension about the general validity of the results presented here. Second, Swiss direct-democratic campaigns take place against the backdrop of a peculiar and well-structured context, characterized by rather intensive campaigns. This may strongly limit the external validity of the results of the empirical analysis. Thus, the number of campaigns and countries in future empirical studies should be increased. However, this requires a substantial effort given that the use of panel surveys seems to be the appropriate method for convincingly detecting possible campaign effects.

From a normative point of view, this study paints a rather ambivalent picture. On the one hand, I show that individuals learn a great deal about the contents of propositions in the case of intensive campaigns. This basic pattern lends support to advocates of direct democracy, as it illustrates that the possibility of participating in decision-making can motivate people to become involved in political issues. On the other hand, I establish that citizens with lower levels of education face significantly greater difficulties in acquiring issue-specific knowledge than those with higher levels of education when complex propositions are at stake. This finding yields some support to critics of direct democracy who maintain that referendums and initiatives are too demanding for ordinary citizens. However, instead of throwing the baby out with the bath water and abandoning direct legislation altogether, it may be worth considering the implementation of specific provisions that could facilitate issue-specific learning by citizens with lower levels of education. These may include investments in political education by means of target group-oriented courses and accessible voting applications about the issues at stake.

\section{Acknowledgements}

This empirical analysis relies on data gathered in the framework of the research project "The strategies of political actors process and message" (NCCR Democracy, University of Zurich), which was financed by the Swiss National Science Foundation. The author would like to thank Alice Simon, Dani M. Marinova, Monica Ferrin, Henry Milner, Martin Elff, and Richard E. Matland for helpful comments on an earlier version of this article. 


\section{References}

Barber, B. R. (1984). Strong democracy: Participatory politics for a new age. Berkeley, CA: University of California Press.

Benz, M., \& Stutzer, A. (2004). Are voters better informed when they have a larger say in politics? Evidence for the European Union and Switzerland. Public Choice, 119(1-2), 31-59. doi:10.1023/B:PUCH.0000024161.44798.ef

Bernhard, L. (2012). Campaign strategy in direct democracy. Basingstoke, England: Palgrave Macmillan.

Bernhard, L. (2018). Lassen sich in der direkten Demokratie die Bürgerinnen und Bürger in ihrem Stimmentscheid durch die Medienberichterstattung beeinflussen? In D. Kübler, (Ed.), Die Rolle der Medien in der direkten Demokratie (pp. 89-102). Zurich, Switzerland: Schulthess.

Bonfadelli, H. (1994). Die Wissenskluft-Perspektive: Massenmedien und gesellschaftliche Integration. Konstanz, Germany: UVK.

Bonfadelli, H. (2005). Mass media and biotechnology: Knowledge gaps within and between European countries. International Journal of Public Opinion Research, 17(1), 42-62. doi:10.1093/ijpor/edh056

Budge, I. (1996). The new Challenge of direct democracy. Cambridge, England: Polity Press.

Cain, B. E., Dalton R. J., \& Scarrow, S. E. (2003). Democracy transformed? The expanding political opportunities in advanced industrial democracies. Oxford, England: Oxford University Press.

Dahl, R.A. (1956). A preface to democratic theory. Chicago, IL: The University of Chicago Press.

Delli Carpini, M.X., \& Keeter, S. (1996). What Americans know about politics and why it matters. New Haven, CT: Yale University Press.

Ferrin Pereira, M., Fraile, M., \& Rubal, M. (2015). Young and gapped? Political knowledge of girls and boys in Europe. Political Research Quarterly, 68(1), 63-76. doi:10.1177/1065912914554040

Fraile, M. (2011). Widening or reducing the knowledge gap? Testing the media effects on political knowledge in Spain (2004-2006). The International Jour- nal of Press/Politics, 16(2), 163-184.

doi:10.1177/1940161210388413

Fraile, M. (2013). Do information-rich contexts reduce knowledge inequalities? The contextual determinants of political knowledge in Europe. Acta Politica, 48(2), 119-143. doi:10.1057/ap.2012.34

Frey, B. S. (1997). A constitution for knaves crowds out civic virtues. Economic Journal, 107(443), 1043-1053. doi:10.1111/j.1468-0297.1997.tb00006.x

Goldstein, K., \& Freedman, P. (2002). Lessons learned: Campaign advertising in the 2000 elections. Political Communication, 19(1), 5-28. doi:10.1080/105846002317246461

Gormley, Jr. W. M. (1986). Regulatory issue networks in a federal system. Polity, 18(4), 595-620. doi: 10.2307/3234884

Holbrook, T. M. (2002). Presidential campaigns and the knowledge gap. Political Communication, 19(4), 437-454. doi:10.1080/10584600290109997

Hwang, Y., \& Jeong S.-H. (2009). Revisiting the knowledge gap hypothesis: A meta-analysis of thirty-five years of research. Journalism \& Mass Communication Quarterly, 86(3), 513-532. doi:10.1177/107769900908600304

Iyengar, S., \& Simon, A. F. (2000). New perspectives and evidence on political communication and campaign effects. Annual Review of Psychology, 51(1), 149-169. doi:10.1146/annurev.psych.51.1.149

Kriesi, H. (2005). Direct democratic choice: The Swiss experience. Lanham, MD: Lexington.

Kriesi, H. (2011). Political communication in direct democratic campaigns: Enlightening or manipulating? Basingstoke, England: Palgrave Macmillan.

Kriesi, H., Grande, E., Lachat, R., Dolezal, M., Bornschier, S., \& Frey, T. (2008). West European politics in the age of globalization. Cambridge, MA: Cambridge University Press.

Kriesi, H., \& Trechsel, A.T. (2008). The politics of Switzerland: Continuity and change in a consensus democracy. Cambridge, MA: Cambridge University Press.

Lanz, S., \& Nai, A. (2015). Vote as you think: Determinants of consistent decision making in direct democracy. Swiss Political Science Review, 21(1), 119-139. doi:10.1111/ spsr. 12126 
Lau, R. R., \& Redlawsk, D. P. (2008). An exploration of correct voting in recent U.S. presidential elections. American Journal of Political Science, 52(2), 395-411. doi:10.1111/j.1540-5907.2008.00319.x

Lupia, A. (1994). Shortcuts versus encyclopedias: information and voting behavior in California insurance reform elections. American Political Science Review, 88(1), 63-76 doi:10.2307/2944882

Lupia, A. (2006). How elitism undermines the study of voter competence. Critical Review, 18(1-3), 217-232. doi:10.1080/08913810608443658

Lupia, A., \& Matsusaka, J. G. (2004). Direct democracy: New approaches to old questions. Annual Review of Political Science, 7, 463-482. doi:10.1146/annurev.polisci.7.012003.104730

Milic, T. (2012). Correct voting in direct legislation. Swiss Political Science Review, 18(4), 399-427. doi:10.1111/spsr.12000

Mondak, Jeffrey J. (2001). Developing valid knowledge scales. American Journal of Political Science, 224-238. doi:10.2307/2669369

Nadeau, R., Nevitte, N., Gidengil, E., \& Blais, A. (2008). Election campaigns as information campaigns: Who learns what and does it matter? Political Communication, 25(3), 229-248. doi:10.1080/10584600802197269

Nai, A. (2015). The maze and the mirror: voting correctly in direct democracy. Social Science Quarterly, 96(2), 465-486. doi:10.1111/ssqu. 12154

Pateman, C. (1970). Participation and democratic theory. Cambridge, MA: Cambridge University Press.

Sartori, G. (1987). The theory of democracy revisited. Chatham, England: Chatham House.

Schumpeter, J.A. (1942). Capitalism, socialism, and democracy. New York: Harper.

Smith, D. A., \& Tolbert, C. J. (2004). Educated by the initiative: The effects of direct democracy on citizens and political organizations in the American States. Ann Arbor, MI: University of Michigan Press.

Smith, D. A., \& Tolbert, C. J. (2007). The instrumental and educative effects of ballot measures: Research on direct democracy in the American states. State
Politics \& Policy Quarterly, 7(4), 416-445. doi:10.1177/153244000700700404

Smith, M.A. (2002). Ballot initiatives and the democratic citizen. The Journal of Politics, 64(3), 892-903. doi:10.1111/00223816.00151

Sniderman, P.M. (1993). The new look in public opinion research. In A.W. Finifter (Ed.), Political science: The state of the discipline II (pp. 219-245). Washington, D. C.: American Political Science Association.

Tichenor, P. J., Donohue, G. A., \& Olien, C. N. (1970). Mass media flow and differential growth in knowledge. Public Opinion Quarterly, 34(2), 159-170. doi:10.1086/267786

Verba, S., Kim, J., Nie, N.H., \& Kim, J. (1978). Participation and political equality. A seven-nation comparison. Cambridge, MA: Cambridge University Press.

Zaller, J. R. (1996). The myth of massive media impact revisited. In D. C. Mutz, P. M. Sniderman, \& R.A. Brody (Eds.), Political persuasion and attitude change (pp. 17-78). Ann Arbor, MI: University of Michigan Press.

Zaller, J. R. (1992). The Nature and Origins of Mass Opinion. Cambridge, MA: Cambridge University Press. 


\section{Appendix}

Table A.1: Ordered probit regression models explaining initial knowledge levels

\begin{tabular}{|c|c|c|c|}
\hline Variables & $\begin{array}{l}\text { Asylum } \\
\text { (1) }\end{array}$ & $\begin{array}{l}\text { Naturalization } \\
\text { (2) }\end{array}$ & $\begin{array}{c}\text { Corporate tax } \\
\text { (3) }\end{array}$ \\
\hline Education level & $\begin{array}{l}0.041^{* * * *} \\
(3.49)\end{array}$ & $\begin{array}{r}0.004 \\
(0.31)\end{array}$ & $\begin{array}{l}0.008 \\
(0.60)\end{array}$ \\
\hline Political interest & $\begin{array}{l}0.353^{* * *} \\
(6.51)\end{array}$ & $\begin{array}{l}0.129^{*} \\
(2.24)\end{array}$ & $\begin{array}{l}0.246^{* * *} \\
(4.27)\end{array}$ \\
\hline Woman & $\begin{array}{l}-0.049 \\
(-0.68)\end{array}$ & $\begin{array}{r}0.061 \\
(0.74)\end{array}$ & $\begin{array}{l}-0.127 \\
(-1.55)\end{array}$ \\
\hline Age & $\begin{array}{l}0.018 \\
(1.45)\end{array}$ & $\begin{array}{l}-0.018 \\
(-1.21)\end{array}$ & $\begin{array}{l}-0.012 \\
(-0.86)\end{array}$ \\
\hline $\mathrm{Age}^{2}$ & $\begin{array}{l}-0.0002 \\
(-1.55)\end{array}$ & $\begin{array}{l}0.0002 \\
(1.47)\end{array}$ & $\begin{array}{l}0.0002 \\
(1.38)\end{array}$ \\
\hline Left & $\begin{array}{l}0.199^{*} \\
(2.36)\end{array}$ & $\begin{array}{l}-0.105 \\
(-1.12)\end{array}$ & $\begin{array}{r}0.056 \\
(0.59)\end{array}$ \\
\hline Moderate right & $\begin{array}{c}0.018 \\
(0.21)\end{array}$ & $\begin{array}{l}-0.083 \\
(-0.80)\end{array}$ & $\begin{array}{r}0.140 \\
(1.39)\end{array}$ \\
\hline TV attention & $\begin{array}{r}0.011 \\
(0.09)\end{array}$ & $\begin{array}{l}0.068 \\
(0.47)\end{array}$ & $\begin{array}{r}0.025 \\
(0.17)\end{array}$ \\
\hline Newspaper attention & $\begin{array}{l}0.028 \\
(0.24)\end{array}$ & $\begin{array}{r}0.083 \\
(-0.73)\end{array}$ & $\begin{array}{r}-0.153 \\
(-1.14)\end{array}$ \\
\hline N & 1035 & 990 & 990 \\
\hline Pseudo $\mathrm{R}^{2}$ & 0.033 & 0.008 & 0.025 \\
\hline
\end{tabular}

Note. Z-Values in parentheses.

${ }^{*} p \leq 0.05,{ }^{* *} p \leq 0.01,{ }^{* * *} p \leq 0.001$.

Supporters of the radical right serve as reference category for the political camp. 